Fecha de recepción: marzo 2020 Fecha de aceptación: abril 2020 Versión final: mayo 2020

\section{The Role of Personal Image in Personal Branding}

Sonia Dubey Dewan ${ }^{(1)}$

\begin{abstract}
Personal branding is an ongoing process of developing and maintaining a reputation and impression of an individual, group, or organization. The role of image is considered to be very limiting when it comes to personal branding, especially while maintaining the reputation and impression. There is enough evidence present that personal image plays a vital role in various stages of personal branding. In this study, we study the role of personal image in personal branding through three stages - a) discovering and crafting the personal brand; b) expressing; c) finally maintaining and enhancing the personal brand. The study provides insights and share case studies related to this topic.
\end{abstract}

Keywords: Personal branding - Image Management - Personal Image - Image Building Branding.

[Abstracts in spanish and portuguese on the page 38]

(1) Sonia Dubey Dewan, AICI CIP, is the Managing Partner of the Indian School of Image Management (ISIM). She is an Entrepreneur, an International Keynote Speaker, and the first AICI Certified Image Professional (CIP) in India chapter.

Dubbed as a "Fairy Godmother of Transformation" by a leading news publication, Sonia dons many hats, including the President of AICI India Chapter. With over 11 years of experience in the field of Image Management, Personal Branding \& Training India's \& Mauritius's top companies \& startups are among her corporate clients along with many C-suite executives, entrepreneurs, socialites, celebrities \& politicians are her clients.

Sonia is the President of the AICI India Chapter for the 2019-2021 term and was Awarded as the Chapter Member of the year for 2019 by AICI Global. She has completed the Image Management \& Consulting Programs by International Image Institute, Canada; ByFerial Image Consultants, Florida, USA; and ICBI, curriculum partner of Conselle Institute of Image Management.

A master's in business administration (MBA) from IBS Pune, Sonia has achieved Trainthe-Trainer from Dale Carnegie Training. She is also a WSET Level 1 and Certified Yoga Instructor.

The Editor-in-Chief of AICI Global Magazine, she has been featured in various national and local TV Channels and Newspapers such as News24, Times of India, Economic Times, Entreprenuer.com, to name a few. She regularly contributes to newspapers, magazines, and blogs. With her customized, empathetic, and inspirational approach, Sonia is known for her motivational, exuberant yet elegant, and always open to sharing quality. Sonia quotes, "You are your most valuable asset, start investing in it today." 


\section{Defining Personal Branding}

Personal branding is the practice of marketing people and their careers as brands. It is an ongoing process of developing and maintaining a reputation and impression of an individual. Some self-help books and practices focusing on self-improvement, mention that personal branding is the way to achieve success by self-packaging. There is not enough evidence of the origin of the term, but the practice was first introduced in 1937 in the book Think and Grow Rich by Napoleon Hill. Later, mentioned in many other books and finally popularized by Tom Peters.

According to Bard Papegaaij, research director at Gartner, a personal brand is more essentially determined by what one believes in, how one behaves and what people think one believes in.

\section{Why is it Important?}

One of the main benefits of personal branding is that an individual can present themself in the best possible light to achieve their knowledge commerce business goals.

Personal branding allows permission to be authentic. The idea of fully accepting oneself helps gains confidence. Authenticity leads to confidence.

There is enough evidence that shows that personal brand helps to gain the trust of people, building credibility. This help in gaining much higher perceived value

Personal branding makes one the "go-to" person in their area of expertise for their specific audience. It helps one become the thought leader in their field

$100 \%$ authentic personal brands also differentiate them from the competition leading to attracting ideal opportunities in one's personal, professional, and social life.

\section{Stages of Personal Branding}

a. Discover \& Craft a Personal Brand:

Building a personal brand means providing so much value in one (or multiple) niche(s) that people begin to associate your name with the idea of what it means to be successful in that industry. It helps become a thought leader and an influencer.

Building a personal brand takes a systematic step by step approach.

Here is the overview:

Identifying the true nature of oneself, their values, what they stand for is a crucial step to establish the personal brand. To outshine the personality, identify strengths, and the most critical aspect is to know the weaknesses so that one can work on minimizing them.

Each individual is unique, unique because of the family one is born in, teaching, the school or college one go to, one's place of work, people one spends their time with, their loved ones, friends, relatives, colleagues, acquaintance. The experiences in personal, professional, and social lives define the personality. The life one lives, and the way one lives it, 
the places one goes to, how one spends their time, where one spends our time and money, defines one's lifestyle.

b. Expressing a Personal Brand:

A personal brand is not a brand until one does not express it to the target audience. It is the target audience, which consumes the external representation of a product or a person and creates a perception in their mind, which we call as a brand. Drawing analogy from the concept of branding, when launching a brand for the first time, a logo is unveiled with the brand colors. A tag line reveals describing what does the brand stands for. Series of advertisements, events, promotions, or social media campaigns are all part of the same brand messaging. All these steps create a perception in our minds. It stimulates feelings, which establishes the way we define the company, product, or person as a brand.

Similarly, with people, it is the expression of who they are and their personality through various channels of external communication. These external channels create a connection between the target audience and the person by stimulating feelings and reactions and personal imagery in the mind of others, which ends up becoming a personal brand. Some of the external channels of communication are presence, posture, walking style, clothing style, the colors, the fabric, accessories, grooming, hygiene, health and wellness, style of communication, tonality, vocabulary, presentation style.

With social media and digital platforms becoming part of our daily lives, showcasing and expressing oneself on all digital platforms using all channels of communication is not vanity but a necessity. Adding up to the expression of a personal brand.

c. Managing \& Enhancing Personal Brand

Personal branding is not a one-time event.

Just like oneself, one's brand is ever-evolving. One can repeat the process used to discover, document, distill, validate, and create a personal brand as many times over a lifetime. It is a proven process to help one make great choices at every juncture in their life. The questions answered in this process are of paramount importance, whether one is attending college or making a key career or life decisions.

The answers to the questions asked in the discovery and crafting stage enable one to fulfill a life filled with engagement and enthusiasm derived from living in alignment with values, passions, strengths, and skills that fulfill a purpose.

As one gains experience and grows, their skills and interests will evolve and grow along the process. In time, one may want to revisit the process and perform the exercises again to identify strengths and areas for development, and to help drive one's brand plan. It might even be fun to revisit it when a 10-year college reunion rolls around.

\section{Defining Image \& Image Management}

According to the Oxford dictionary, image is a noun. A representation of the external form of a person or thing in art. Synonyms, likeness, and resemblance 
Or

The general impression that a person, organization, or product presents to the public.

'she strives to project an image of youth' Synonym: impression, persona, profile, identity, face, front, role, part, mask, façade, guise

An image is a picture or other representation of a person or thing, or it can be someone's public perception, like a rock star who tries to change his image by dressing like a professor and learning to play chess.

In short, an image is "You," in the eyes and minds of others. A picture another person has of us. Moreover, who one is in the eyes and mind of others is projected consciously and unconsciously by the way one looks, care for and carry oneself, through personal style, poise, and presence. It reflects who one is on the inside, their personality, values, attitudes, interests, abilities, uniqueness, roles, and often goals.

Image influences public perception of oneself, a perception that results in an impression. The image becomes the identity of a person, through assessment, evaluation, judgment based on the image one project or reflect. Assessment is automatic, occurs in seconds, and influences the achievement of their goals.

\section{Image Management}

Image Management is an ongoing conscious process of evaluating and enhancing our image and how others perceive us and therefore respond to us. It is about creating first impressions and, more importantly, an impactful presence. It gives us the power to control, modify, or improve the image that we want to project to others.

Image Management is creating an authentic, appropriate, attractive, and affordable personal and professional image, increasing one's confidence, credibility, capability, and productivity while contributing to continuing success.

It includes an understanding of oneself, tastes, likes \& dislikes, personality, roles \& goals achieved by using the three resources of image management:

- Appearance

- Behavior

- Communication

The ABC of Image.

These three resources, in perfect alignment of our goals, dreams, personality, values, and lifestyle, helps us create an authentic image of ourselves.

\section{Role of Image in Personal Branding}

Personal branding is based on the self-presentation theory by Erving Goffman, who explores the way people want to be seen and how their peers perceive them. Goffman uses the term Dramaturgy to describe looking at one's persona as a drama, treating one's ac- 
tions as an actor in a play. One can control how their peers view them, and in the case of celebrities or athletes, can build a personal brand by utilizing what they present to their publics using various social media outlets. Self-presentation theory and personal branding go hand in hand. We see celebrities and athletes building a particular brand or persona over with the use of Twitter, Facebook, Instagram, and Snapchat. Building a personal brand is a big part of a celebrity's life, and it can help them spread awareness and also provide an outlet to connect with their fans/supporters. Reaching to a broader audience is made possible through the use of social media and the ability of the person looking to build a personal brand to make their messages heard. The theory of self-presentation explores how people look to create an identity for themselves that they would like to be seen as by their peers or in the public eye. This self-presentation to the external world is what Goffman calls the front stage.

Image Management is also known as self-presentation, self-promotion, and professional presence. It is an effective way to attract others-to encourage others to regard one favorably and with continued interest. Positive self-presentation is an open invitation to become acquainted with the person inside. It is an effective way to influence the opinion or actions of others. Effective personal image management aids one in achieving personal and professional success.

Hence, it is clear the image management helps in creating what Goffman calls as the front stage of personal branding. In this study further, we will explore the role of image management in each stage of personal branding.

\section{A. Role of Image Management in Discover/Craft Stage of Personal Branding}

The first stage of a personal brand is to discover one's true self. It is when one knows themselves truly, one can do a better job crafting, expressing, and managing a personal brand. There are four areas to identify to discover one's brand, and those are:

- Values

- Swot Analysis

- Personality

- Lifestyle

Values: As per the Oxford dictionary, it is a belief about what is right and wrong and what is essential in life.

Values are individual beliefs that motivate people to act one way or another. They serve as a guide for human behavior. Generally, people are predisposed to adopt the values that one is raised with. People also tend to believe that those values are "right" because they are the values of their particular culture. Few examples of values could be honesty, peace, justice, beauty, ambition.

SWOT Analysis:

SWOT analysis (or SWOT matrix) is a strategic planning technique used to help a person identify strengths, weaknesses, opportunities, and threats related to business competition 
or project planning. It is used in the preliminary stages of the decision-making processes of a brand. It is also a tool for evaluation of the strategic position of a personal brand during the managing and enhancing stage.

Users of a SWOT analysis often ask and answer questions to generate meaningful information for each category to make the tool useful and identify their competitive advantage. SWOT is described as the tried-and-true tool of strategic analysis but often also criticized for its limitations.

Strengths and weaknesses are frequently internally-related, while opportunities and threats commonly focus on the external environment. The name is an acronym for the four parameters the technique examines:

- Strengths: characteristics of a person that give them an advantage over others. It includes professional qualifications, work experience, skills, abilities, any other expertise or talent.

- Weaknesses: characteristics of a person that place the person at a disadvantage relative to others. For example, lack of required skills, qualification, experience for success. Bad habits, patterns, or beliefs are also weaknesses.

- Opportunities: elements in the environment that the person could exploit to its advantage. Possible examples: A significant/change or advancement in the external scenario, which is shifts the tide in one's favor. New place, position, technology, or role.

- Threats: elements in the environment that could cause trouble for the person. For example, competition, adverse demographic changes, change in government policies, or economic slowdown.

\section{Personality}

Personality is defined as the unique sets of behaviors, cognitions, and emotional patterns that evolve from biological and environmental factors. Identifying one's personality gives a better understanding of all different reactions and perceptions for a thing, place, situation, or even another person. It helps in making a relationship better with other people By learning more about where one lies on the extroversion/introversion and thinking/ feeling continuums, one might be better able to understand why one prefer certain things and dislike others. Learning more about one's personality type can also help discover new ways to approach problems.

The process of image building and image management entirely relies upon and starts from the process of knowing one's personality, as it defines the most fundamental true nature of oneself.

\section{Lifestyle}

As per the Cambridge Dictionary, lifestyle is one's way of living; the things that a person or a particular group of people usually do.

The broader sense of lifestyle as a "way or style of living" has been documented since 1961. Lifestyle is a combination of determining intangible or tangible factors. Tangible factors relate specifically to demographic variables, i.e., an individual's demographic profile, whereas intangible factors concern the psychological aspects of an individual, such as personal values, preferences, and outlooks. 
In the context of personal branding, lifestyle helps identify a person's social position, style of thoughts, and style of actions. Whereas from the personal image perspective, it helps identify habits, activities, hobbies, interests, health, nutrition, socializing, and more, which in turn impacts the image of the person. A simple example, a vegan person will have a personal image of being more healthier, environmentally friendly, and against animal cruelty. Their lifestyle supports the perception because they follow a vegan diet; they go to vegan restaurants, attend events about the vegan lifestyle, buy sustainable items, have friends who eat vegan food, and also propagate the idea of veganism. From a personal brand perspective, this individual could establish a robust social position by sharing their thoughts and taking actions in the vegan community.

Upon the successful discovery of values, SWOT, personality, and lifestyle, one could collect all this information to craft a personal brand profile. This personal brand profile lays out the personal image that one would like to create, How one would like to be seen, speak, walk, talk, communicate, or behave. Most importantly, the personal brand profile helps craft a Unique Selling Proposition (USP) of a person. This unique selling proposition is similar to the tagline of a brand. It is a personal brand statement.

\section{B. Role of Personal Image in Expressing Personal Brand}

The process of discovery and crafting a personal brand is followed by the process of expressing the personal brand to the world. This stage of a personal brand relies heavily on the elements of Personal image, creating imagery or identity through various resources, skills, tools of image management.

\section{Expressing personal brand through resources of image management}

The first resource of image management, appearance, includes three dimensions.

- Clothing \& Grooming

- Body Language

- Physical Characteristics

Clothes are one of the most significant resources to create a personal image constituting almost $90 \%$ of appearance dimensions. Clothing and grooming can modify the other two dimensions, i.e., body language and physical characteristics.

Therefore, it can support the personal brand one wishes to create. Clothing to a person is what packaging of a product is to a brand. The product packaging is a way of reassuring everything the brand promises. Not only that, but it is also a culmination of the brand logo, colors, and design that creates an identity in the mind of the user. It is a way of creating credibility with the repetition of the brand message.Similarly, clothing for a person is a resource to show their values, their strengths, and weaknesses, their personality as well as lifestyle. The lines, shapes, color, texture, and pattern on a piece of garment worn by a person, communicates a meaning, mood, or a message. 
For example, A health enthusiast would wear clothes that would allow them to not only showcase their healthy body but allows flexibility to show off their skills in any given situation which supports their lifestyle.

Grooming, hygiene, and overall physical representation contribute to overall personal image. A cabin crew staff could be easily identified even off duty by the way they maintain their physical well being and grooming.

Clothing and grooming can modify the body language of the person. For example, a power suit makes one posture more dominant by giving an instant boost in the feeling of the power of authority. Putting on a suit does not just change how one looks; it can change the way one perceives the world and make one think more broadly, a new US study suggests. After testing people's thought patterns in relation to the formality of their attire, researchers found that suit-wearers felt more powerful, and this encouraged them to think about the big picture rather than getting hung up on the details. Alternatively, in psychology terms, donning a suit encouraged 'abstract processing' rather than 'concrete processing.' "Putting on formal clothes makes us feel powerful, and that changes the basic way we see the world," the lead researcher, psychologist Abraham Rutchick from California State University, Northridge.

\section{Expressing personal brand through skills and abilities}

Skills and abilities such as public speaking, presentation skills, body language, etiquette, or civility, assist in expressing one's brand values, education, personality, or work experience better. Confidence and assertiveness skills help in presenting oneself more confidently in front of the audience and hence creates trust and likeability. These skills are the behavioral and communication resources of a personal image.

For example, Steve Jobs was a tech guru adored by millions around the world for his ability to connect with people using his oratory \& public speaking skills. His body language \& behavior consistently positioned his brand as a visionary, a rule-breaker \& a perfectionist. By using his communication skills, he was able to truly create a personal brand \& followers like no other in the world.

\section{Expressing personal brand through online and offline tools}

A personal brand is commonly first expressed through offline tools such as business card, resume, or photographs. These offline tools use plenty of personal image resources, predominately appearance, followed by communication. The fonts, colors, words, and tone used in the resume, "thank you" cards or business letter says a lot about the person.

A photograph creates the first impression, with the cues from the resources of appearance such as clothing color, lines, patterns and shapes, grooming and facial expression, and body posture, in turn, giving a chance to create likeability.

Online tools such as websites, social media blogs, videos, or posts amplify the usage of personal image resources - appearance, behavior, and communication to a much more amplified level. The first way to create a strong personal brand is to create strong visual imagery through eye-catching, creative videos, and posts. The importance of appearance through clothes, grooming, posture, facial expression is paramount. 
A great example of this is Tony Robbins, people either love him or loathe him, but it would be hard to find anyone unfamiliar with his brand of financial self-help. Looking back at the early 1990 version of Tony was loud \& energetic, parading in front of his adoring fans. His identity changed over time; today, he is no longer screaming from the stage but is more sophisticated and subdued. The brand is consistent in its message on his current website, where he is not positioned as a self-help guru or a self-empowerment prophet but as a financial teacher or someone from the tech industry.

His website showcases a personal brand that's contemporary and relevant to the current times.

\section{Role of Personal Image in Managing/Enhancing Personal Brand}

A personal brand is what people expect from a person. It is more about creating the perception. Image management is more about maintaining this perception. For example, a person might have a personal brand of 'being a technology savvy".

When asked questions about new technology, they will have to reply in order to manage or maintain their 'image.' Not being aware of new technology will damage their reputation.

Personal branding is to create a reputation in the market. Image Management is meaning to maintain the image which is created by personal branding. Managing and enhancing also requires collaboration with experts from different domains such as public relations, marketing agencies, digital marketing agencies, life coaches, leadership coaches, and many more.

\section{Conclusion}

Personal Image and Personal Branding are entirely different. A Personal image is due to the visual depiction of our appearance, behavior, communication, in our personal and digital lives. In contrast, a personal brand is a holistic representation of oneself, which includes the depiction of personal image and our passions, values, strengths, education, work experience, and skills. However, in order to create a successful personal brand, one must work with a personal image in conjunction.

\section{Citations}

Think \& Grow Rich - Napoleon Hill 1937

Lair, Daniel J.; Sullivan, Katie \& Cheney, George (2005). "Marketization and the Recasting of the Professional Self.” Management Communication Quarterly. 18 (3): 307-343. doi:10.1177/0893318904270744.

Creating Your Personal Brand - Los Ellis 2009

The Triumph of Individual Style: A Guide to Dressing Your Body, Your Beauty, Your Self https://ethicsunwrapped.utexas.edu/glossary/values 
https://en.wikipedia.org/wiki/SWOT_analysis

Corr, P. J. \& Matthews, G. (2009). The Cambridge handbook of personality psychology (1.

publ. ed.). Cambridge: Cambridge University Press. ISBN 978-0-521-86218-9.

https://dictionary.cambridge.org/dictionary/english/lifestyle

https://www.sciencealert.com/research-shows-wearing-a-suit-changes-the-way-you-think

Resumen: La marca personal es un proceso continuo de desarrollo y mantenimiento de la reputación e impresión de un individuo, grupo u organización. Se considera que el papel de la imagen es muy limitante cuando se trata de la marca personal, especialmente mientras se mantiene la reputación y la impresión. Hay suficiente evidencia presente de que la imagen personal juega un papel vital en varias etapas de la marca personal. En este estudio, estudiamos el papel de la imagen personal en la marca personal a través de tres etapas: a) descubrir y crear la marca personal; b) expresarse; c) finalmente mantener y mejorar la marca personal. El estudio proporciona información y comparte estudios de casos relacionados con este tema.

Palabras clave: marca personal - gestión de imagen - imagen personal - creación de imagen - marca.

Resumo: A marca pessoal é um processo contínuo de desenvolvimento e manutenção da reputação e impressão de um indivíduo, grupo ou organização. O papel da imagem é considerado muito limitador no que diz respeito à marca pessoal, principalmente mantendo a reputação e a impressão. Atualmente, existem evidências suficientes de que a imagem pessoal desempenha um papel vital em vários estágios da marca pessoal. Neste estudo, estudamos o papel da imagem pessoal na marca pessoal através de três etapas: a) descoberta e criação da marca pessoal; b) expressar; c) finalmente manter e aprimorar a marca pessoal. O estudo fornece informações e compartilha estudos de caso relacionados a este tópico.

Palavras chave: marca pessoal - gerenciamento de imagem - imagem pessoal - criação de imagem - marca.

[Las traducciones de los abstracts fueron supervisadas por el autor de cada artículo] 